\title{
The Body Composition of Low Value Fish and their Preparation into a Higher Value Snack Food
}

\author{
Oduor-Odote, P. M and Kazungu, J.M. \\ Kenya Marine and Fisheries Research Institute, P.O. Box 81651, Mombasa, Kenya
}

Key words: Galeichthys feliceps, Trichurus lepturus, fish snack, body composition

\begin{abstract}
In Kenya, marine catfish (Galeichthys feliceps) and ribbonfish (Trichurus lepturus) are both under- utilized species from the prawn fishery where they occur as by-catch or discards. They represent a potentially valuable source of protein mince. The current study assessed the feasibility of increasing the value of this by-catch by testing its suitability to the production of snack foods which was prepared with locally available flour from rice, wheat and maize. The ratio of fish mince to flour, the carbohydrate component, was tested in the snack foods at rations of $2.5: 1 ; 2: 1$ and $1: 1$. An untrained taste panel using a hedonic scale of 1 to 9 tested preference. Protein content, fat, moisture, amino acid and fatty acid composition are reported and both indicate the nutritional suitability of the selected fish. The overall order for preference was ribbonfish with rice then ribbonfish with wheat, catfish with rice, ribbonfish with maize and catfish with wheat. Rice was preferred for value addition and ribbonfish was the preferred fish in the formulations.
\end{abstract}

\section{INTRODUCTION}

The production of fish in Kenya was estimated to be 180,000 tonnes in the last decade. Coastal fisheries accounted for about 10,000 tonnes per year while 350 tonnes per year was realized from the prawn fishery. Wastage in terms of by-catch, fish discards, and low value and or under-utilized fish from the prawn trawl fishery was estimated to be 1,800 tonnes per annum (KMFRI- Ungwana Bay report, 2002). This by-catch is a significant portion of the fishery resource that is not currently utilized for human consumption due to the lack of technology, handling, or process methods to transform the fish into stable and acceptable products. In addition, such fish are not utilized, or available for human consumption because they are either small, bony, devoid of taste, un-economical to process, and may not be landed by trawlers due to storage limitations. There exists an opportunity of incorporating local staple cereals, like maize flour in the fish mince protein isolate and making dried products. Worldwide, several value-added mince fish products have been developed (Bello\& Piggot, 1980; Yu, 1991; Akamine et al, 1993; Destura and Haard, 1999, Mathews et al, 2003) and continue to be developed. In Kenya, value added Nile perch products have been developed but they require refrigeration (Ogunja, 1996). There are no fish products that are shelf stable, easily stored and available to lower income households. Many school children depend on snack foods for their meals. Snack foods like fried cassava, though popular with students and children, do not normally contain adequate protein content. Malnutrition is an important contributor to child and infant mortalities. Accordingly, there is a growing need of, with emphasis being placed on processing and utilizing protein rich foods. Fish by-catch species offers a good source to meet this demand, as it is a relatively cheap source of protein. Low value fish or by-catch mixed with staple cereals could offer one source of utilizable protein presented in a different form 
of appearance, shape or taste, as snacks, porridge, crackers or other light foods.

In this study, two fish species Catfish (Galeichthys feliceps) and Ribbonfish (Trichiurus lepturus) were selected for use in developing value-added, shelfstable products. They are usually landed by prawn trawlers in the Ungwana bay area in the North coast of Kenya (KMFRI- Ungwana Bay report, 2002). Muraleedharan and Gopakumar (1997) and Muraleedharan et al, (1996) developed some valueadded mince products from them. Carbohydraterich grain products contribute a large portion to human diets. Maize, millet, wheat, rice are the more common ones among others. They are milled via a process that removes the bran and the germ. While this gives the grains a finer texture and improved shelf life, it also removes dietary fiber, iron and many B-vitamins. Importantly, grain flour does not contain enough protein to sustain individual health needs. In Kenya for example, where $50 \%$ of the population lives on less than one dollar a day, the principal diet of many is only the carbohydraterich grain products as they are unable to afford any portion of animal protein.

Meanwhile, from the marine fishery of Kenya, a substantial amount of fish is lost from shrimp trawlers as by-catch, fish of low value, or other discards. The combination of milled grains and bycatch fish protein offer a potential alternative to the protein-limited and low-nutrition products currently common among the poorer sectors of many coastal communities. The emphasis in this study is on the overall nutritional composition of the fish and the acceptability of the product being developed.

\section{MATERIALS AND METHODS}

\section{Sample handling and preparation for nutritional (proximate value) analysis}

The fish Galeichthys feliceps (catfish) and Trichurus lepturus (ribbonfish) were purchased from Southern Engineering Company Ltd Mombasa in March and June 2003 where they are normally kept in refrigerated containers at $-18{ }^{\circ} \mathrm{C}$. They were transferred to the freezer in KMFRI, $10 \mathrm{~km}$ away and stored at $-20{ }^{\circ} \mathrm{C}$.
The fish were then thawed, graded organoleptically for appearance, odour, colour, shape of eyes, gills and resilience of skin, according to Shewan et al, (1953) and Warm et al (1998). Most fish were graded and found to be of grade 2 of freshness. They were then skinned, filleted, minced, using a manual meat mincer, packed in $1 / 4$ $\mathrm{kg}$ seal-lock bags and returned to the freezer. Some were packed in an ice box with ice and airlifted to the University of Surrey UK overnight, stored in a chest freezer for 24 hours and later transferred to a freezer at $-80{ }^{\circ} \mathrm{C}$ until analysis. Prior to analysis the mince was thawed in a refrigerator overnight at $4{ }^{\circ} \mathrm{C}$.

The Kjeldahl method was used for protein analysis, the Bligh and Dyer method (1959) for fat analysis, and moisture and ash determination according to AOAC methods (1990). The fatty acid profile (expressed as Fatty Acid Methyl Esters (FAME) was determined according to Schmarr et al (1996) using a Varian Gas chromatograph 3400 GC with column (Omega wax TM fused silica capillary column) $30 \mathrm{~m} * 32 \mathrm{~mm}$ and i.d. $0.25 \mu \mathrm{m}$ film thickness (SUPELCCO, Poole, UK). Amino acids were measured according to Bidlingmeyer et al (1984) while the organoleptic assessment was conducted according to descriptions in Shewan et al (1953) and Warm et al (1998).

\section{Preparation of protein isolate}

Whole fish specimens of T. lepturus and G. feliceps were filleted, skinned and minced. Oil was removed from the mince by washing with sodium hydrogen carbonate at the ratio of $5 \mathrm{~kg}$ fish mince to 20 liters of water with $100 \mathrm{~g}$ sodium hydrogen carbonate $(0.5 \%)$. The mixture was mixed vigorously in a plastic basin and then left to stand. Upon settling, the upper, floating layer of fat was gently removed. Before subsequent rounds of washing, the mince was strained and squeezed in a cheese cloth to drain as much liquid as possible. The whole process of washing the mince was repeated three times and at each stage, the fat content of the mince was determined. The strained flesh was transferred to a solar tent dryer and spread on the black polythene covering the rack, and left to dry for 3-4 days. The temperature of air in the solar dryer was monitored and was around $50^{\circ} \mathrm{C}$ on average, on a hot day. The 
dried isolate was then ground in a blender to fine powder, transferred to seal-lock bags and kept in a shelf in the laboratory at ambient temperatures for later use.

\section{Formulation /Preparation of snack food ("kmfri fish cracker")}

The formulation used for the snack food was fish protein isolate to flour ratio of $2.5: 1 ; 2: 1$ and $1: 1$. Three types of flour used were made from rice, maize and wheat bought from the supermarkets in Mombasa. The method used was based on Siaw et al (1985) with some modifications.

The rest of the ingredients were coriander, fish masala, monosodium glutamate, garlic, salt, sugar and water. The fish-flour mixture and the other ingredients were mixed using a KENWOOD kitchen mixer until a homogenous mixture was obtained. The dough like mixture was then stuffed manually in small polythene casings used commonly by ice cube vendors to sell ice.

The stuffed rolls were then boiled in water for 90 minutes to gelatinize starch under ordinary pressure. After cooking, the rolls were immersed in iced water over-night to reduce cook loss and to facilitate separation of casings.

They were then sliced manually into about $5 \mathrm{~mm}$ thick sizes, dried in an oven at an initial temperature of $45^{\circ} \mathrm{C}$ to prevent case hardening and to a final temperature of $70^{\circ} \mathrm{C}$ to reduce the moisture content. The samples were then fried in hot oil at $200{ }^{\circ} \mathrm{C}$ then left to cool.

\section{Organoleptic evaluation}

The acceptability of the snack food produced with this method was tested by a panel of 10 untrained participants using a hedonic scale of 1-9 where a score of 9 was "like extremely" and a score of 1 , "dislike extremely". A score of 5 was "neither like nor dislike", a score of 6 was "like slightly", a score of seven was "like moderately" and a score of 8 "'like very much". Scores of 4 to 1 were "dislike slightly" to "dislike extremely". The attributes were texture, appearance, flavour and taste.

\section{DATA ANALYSIS}

Mann-Whitney Tests (SPSS) was used to test differences in responses to formulations. All the tests were conducted at $p<0.05$ confidence levels

\section{RESULTS \& DISCUSSION}

The results of the fish body composition analysis reveal a strong similarity between the two fish species, other than the higher fat content of T. lepturus landed in June (see Table 1). The nutritional composition of the two species fell within reported values for fish (Huss, 1995) meaning that they can be utilized for production of other valued fish products. Protein and fat are the major nutrients in fish and their levels help define the nutritional status of the particular organism. The chemical composition of fish varies greatly from one individual to another depending on age, sex, environment and season with protein levels ranging from $16-21 \%$, lipids $0.1-25 \%$, ash $0.4-1.5$ $\%$, moisture $60-81 \%$ with extremes of $96 \%$ having been reported (Huss, 1995).

The diets of both G. feliceps and T. lepturus consist of crayfish, small fish, crabs, and cephalopods, among others (Portsev, 1978; Taylor, 1986). These are high protein prey and could be the reason for the high protein content levels found. Lipids in fish vary greatly, a variation that is closely related to feed intake, migratory, swimming or sexual changes in connection with spawning. G. feliceps spawns from May to July (Granado - Lorencio, 1997) while $T$. lepturus spawns between February to June when feeding intensity increases (Chiou et al 2006) and November-December (Yamada, 1991). The higher fat contents observed could be due to preparation

Table 1. Proximate composition of G. feliceps and T. lepturus caught in March and June 2003

\begin{tabular}{llllll}
\hline Species & \% Protein & $\begin{array}{l}\text { \% Fat } \\
\text { March }\end{array}$ & $\begin{array}{l}\text { \% Fat } \\
\text { June }\end{array}$ & \% Ash & \% Moisture \\
\hline G. feliceps & $20.67 \pm 0.04$ & $0.34 \pm 0.03$ & $2.06 \pm 0.08$ & - & $76.07 \pm 0.03$ \\
T. lepturus & $21.75 \pm 0.57$ & $0.33 \pm 0.07$ & $6.08 \pm 0.11$ & $1.54 \pm 0.07$ & $72.30 \pm 0.00$ \\
\hline
\end{tabular}


for spawning. So far in this study, the identified fatty acids in $G$. feliceps were C20: 3n-6 (cis-8, 11, 14-Eicostatrienoic acid) as a polyunsaturated fatty acid and 16:1 palmitoleic acid. The unsaturated fatty acids detected in T. lepturus were 16:1, 18:1, 18:2, 20:3-Palmitoleic, linoleic and cis-11, 14, 17Eicosatrienoic acid. Over $50 \%$ of fatty acids in the muscle of the two fish are composed of C 22 to C 37 (Table2). It is known that the amount of fat varies greatly in different parts of fish; also different fish in different seasons show an enormous variation in fat content (Brandes and Dietrich, 1953; Icekson et al., 1998). The levels of existing amino acids in the

Table 2. Fatty acid Profile for G.feliceps and T. lepturus caught in March 2003

\begin{tabular}{lll}
\hline Fatty Acid ID & G. feliceps & T. lepturus \\
\hline C12 & 25.628448 & 18.23739 \\
C16 & 6.5846348 & 10.91665 \\
C18 & 1.6065544 & 16.04829 \\
C22 & 17.940609 & 9.249557 \\
C23 & 7.5408563 & 2.479467 \\
C32 & 1.5197609 & 2.721562 \\
C33 & 2.5765088 & 12.57311 \\
C35 & 11.383698 & 12.68791 \\
C34 & 13.978307 & 7.694595 \\
C36 & 6.5323461 & 3.099201 \\
C37 & 4.7082767 & 4.292259 \\
\hline
\end{tabular}

Table 3. Amino Acid Profile of G. feliceps and T. lepturus caught in March 2003

\begin{tabular}{lll}
\hline Amino acids & G. feliceps & T. lepturus \\
\hline asp & $6.91 \pm 1.0$ & $6.5 \pm 0.7$ \\
glu & $10.9 \pm 1.0$ & $10.8 \pm 0.68$ \\
h. pro & $1.23 \pm 0.57$ & $1.99 \pm 0.09$ \\
ser & $4.49 \pm 0.4$ & $4.96 \pm 0.1$ \\
gly & $6.73 \pm 0.21$ & $7.25 \pm 0.29$ \\
his & $0.64 \pm 0.28$ & $0.99 \pm 0.32$ \\
arg & $7.7 \pm 0.26$ & $5.89 \pm 0.2$ \\
thr & $4.42 \pm 0.08$ & $4.51 \pm 0.16$ \\
ala & $10.68 \pm 0.18$ & $9.98 \pm 2.77$ \\
pro & $3.09 \pm 1.0$ & $3.44 \pm 0.12$ \\
tyr & $4.09 \pm 0.93$ & $4.73 \pm 0.15$ \\
val & $5.6 \pm 0.29$ & $5.98 \pm 0.32$ \\
met & $2.5 \pm 0.37$ & $2.41 \pm 0.67$ \\
cys & $1.14 \pm 0.26$ & $1.16 \pm 0.09$ \\
I leu & $4.08 \pm 0.11$ & $4.2 \pm 0.17$ \\
leu & $7.81 \pm 0.15$ & $7.88 \pm 0.38$ \\
phe & $3.31 \pm 0.09$ & $3.29 \pm 0.09$ \\
trp & $6.58 \pm 0.52$ & $6.49 \pm 0.54$ \\
lys & $8.06 \pm 0.82$ & $7.49 \pm 0.7$ \\
\hline
\end{tabular}

fish muscles in both species were high, indicating nutritional suitability (Table 3 ).

\section{Product preference}

Regarding preference for the test products, using the formulation of ribbonfish to rice and ribbonfish to maize at 2.5:1, 2:1 and 1:1, there was a significant difference in response between them with more participants preferring the ribbonfish to rice at all the ratios (Table 4). There was a significantly greater preference for ribbon with rice compared to ribbonfish- wheat combination at 2.5:1 and 1:1 respectively. These were indications that rice is preferred to both wheat and maize as the binding ingredient. There were also differences in response between ribbonfish and catfish in the formulations. Between ribbonfish and rice and catfish and

Table 4. Responses of taste panelists to preferences for various formulations of Ribbonfish and Catfish formulations to wheat, rice and maize (Sig. Difference 0.000 means value was too low or significance was high)

\begin{tabular}{lcc}
\hline Formula & Mean Rank & $\begin{array}{c}\text { Sig. Difference } \\
(\mathbf{P}<\mathbf{0 . 0 5})\end{array}$ \\
\hline Ribbonfish-Rice 2.5:1 & 193.71 & $0.000(<<0.05)$ \\
Ribbonfish Maize 2.5:1 & 147.29 & \\
Ribbonfish-Rice 2:1 & 190.76 & $0.000(<<0.05)$ \\
Ribbonfish-Maize 2:1 & 150.24 & \\
Ribbonfish-Rice 1:1 & 191.22 & \\
0.000 (<<0.05) & & \\
Ribbonfish-Maize 1:1 & 149.78 & \\
Ribbonfish-Rice 2.5:1 & 182.88 & \\
0.018 & & \\
Ribbonfish- Wheat 2.5:1 & 158.12 & \\
Ribbonfish-Rice 1:1 & 184.29 & \\
0.009 & & \\
Ribbonfish- Wheat 1:1 & 156.71 & \\
Ribbonfish-Rice 2.5:1 & 182.04 & 0.027 \\
& & \\
Catfish-rice 2.5:1 & 158.96 & \\
Ribbonfish-Rice 2.5:1 & 195.35 & $0.000(<<0.05)$ \\
Catfish-wheat 2.5:1 & 145.65 & \\
Ribbonfish-Rice 2:1 & 194.89 & $0.000(<<0.05)$ \\
Catfish-wheat 2:1 & 146.11 & \\
Ribbonfish- Rice 1:1 & 193.71 & \\
0.000 (<<0.05) & & \\
Catfish- Wheat 1:1 & 147.29 & \\
Ribbonfish-Wheat 2.5:1 & 150.12 & $0.000(<<0.05)$ \\
Ribbonfish-Wheat 1:1 & 190.88 & \\
Ribbonfish-Wheat 2:1 & 157.21 & 0.001 \\
Ribbonfish-Wheat 1:1 & 183.79 & \\
\hline
\end{tabular}


rice at 2.5:1 there was a significant difference in response $(\mathrm{p}<0.05)$ with preference being shown for the ribbonfish and rice combination. This means that ribbonfish is preferred to catfish. This was also observed between ribbonfish to rice and catfish to wheat at 2.5:1, 2:1 and 1:1 respectively. The participants still preferred the ribbonfish formulations. There was a significant difference in response between ribbonfish to wheat at 2.5:1, compared to ribbonfish to wheat at 1:1 with more participants preferring the latter formulation. There was also a significant difference in response between ribbonfish to wheat at 2:1 and 1:1 where 1:1 ribbonfish to wheat was preferred. It would seem that higher amounts of ribbonfish are not desirable in wheat combinations.

The overall order for preference was ribbonfish with rice, then ribbonfish with wheat, catfish with rice, ribbonfish and maize and catfish with wheat. Rice was preferred for value addition and ribbonfish was preferred in the formulations (Table 5). The best product had a score of 6.2 overall which was in the category of "liked slightly". the strength of the dough. If interpretation is based on wheat flour-protein interactions then wheat flour may not be suitable for making the snack. Yu (1991) reported similar results although he used six ingredient combinations from two types of fish and three types of flour (sago, tapioca and wheat). $\mathrm{He}$ also reported that wheat was less suitable. Maize still yielded a better response than wheat combinations although the presence of ribbonfish in the maize may not be ignored.

Rice flour is generally ideal for light-texture recipes and it could conform to the preferences by Kenyans for crunchy light-textured snack products, and crispy snacks (Oduor-Odote PM pers. obs.). Edible fish have a wide range of basic compositions. Fish are either fatty or lean. Particularly with oily fish, both the oil itself and the compounds absorbed in the oil, often dependent on their diet, will influence the flavour of the final product. Sometimes even with leaner fish, higher in protein and water content, chemicals in their diet can penetrate and taint the flesh, affecting the flavour and or colour, or even the odour of the

Table 5 Overall preference per formulation.

\begin{tabular}{lccccc}
\hline Product formula & Ribbonfish-Rice & Ribbonfish-wheat & Catfish-Rice & Ribbonfish-Maize & Catfish-Wheat \\
\hline 2.5: 1 & $6.3 \pm 0.13$ & $5.3 \pm 0.22$ & $5.3 \pm 0.22$ & $4.8 \pm 0.23$ & $4.5 \pm 0.24$ \\
2: 1 & $6.3 \pm 0.16$ & $5.5 \pm 0.24$ & $5.5 \pm 0.23$ & $5.0 \pm 0.23$ & $4.7 \pm 0.25$ \\
$1: 1$ & $6.0 \pm 0.17$ & $6.0 \pm 0.25$ & $5.3 \pm 0.23$ & $4.8 \pm 0.23$ & $4.5 \pm 0.24$ \\
Overall & $6.2 \pm 0.09$ & $5.6 \pm 0.14$ & $5.4 \pm 0.13$ & $4.9 \pm 0.3$ & $4.6 \pm 0.14$ \\
\hline
\end{tabular}

Several factors could come into play considering responses to the formulations. Normally, at least 50 $\%$ or more amylopectin and 5-20\% amylose is required for a good quality product (Matz, 1970). Wheat starch contains $20-25 \%$ amylose, rice 20 $\%$ amylose and maize about the same amount. The compositional requirements are therefore within limits (Yu, 1991). Wheat flour contains up to 15 $\%$ protein, rice $6.5-7 \%$ protein and maize $7-8 \%$. However, wheat flour contains proteins that interact with each other during cooking, forming gluten that is not available in either rice or maize. The protein content of the flour is what is greatly at variance and could be causing the differences in preference. Gluten is high in wheat and is known to suppress expansion during cooking and binds dough during preparation. The protein content of dough affects fish. Differences are due to compositions of the fish, feeding regimes etc. The differences in taste between catfish and ribbonfish could be due to any of the mentioned reasons among others.

\section{CONCLUSIONS}

It can be concluded that the nutritional body composition of the selected fish, including amino acids, is within nutritional ranges required by humans. Fat composition exhibited seasonal variations in both species of fish, with $T$. lepturus having a wider range of highly unsaturated fatty acids than $G$.feliceps. Rice flour was the preferred binding flour in the snack formulations and $T$. lepturus (Ribbonfish) preferred to catfish. 
Acknowledgements: Prof. Nazlin Howell, University of Surrey, UK for funds (EU INCO) and for laboratory space, thanks goes to the Director KMFRI. The assistance of Dr. Farah Badii, University of Surrey, Mr. Shadrack Tunje, Mr. Charles Odoli, Maurice Obiero, and Mr. Bern Fulanda in data analysis is highly appreciated.

\section{REFERENCES}

Akamine,J.S.;Kushima,J.N. \& Iwaoka,W.T.(1993). Formulated Food Products From Previously Frozen Skipjack Tuna Meat. Journal of Aquatic Product Technology. Vol 2(1)23-34.

AOAC (1990). Official Methods Of Analysis: Association Of Official Analytical Chemists International, Airlington, U.S.A.pp 931. 341342; 449.

Bello,R.A.\& Piggot, G.M (1980). Dried Fish Patties: Storage Stability and Economic Considerations. Journal of Food Processing and Preservation 4: $247-260$

Bidlingmeyer,B.A.; Cohen, S.A.\& Tarvin, T.L. (1984). Rapid Analysis of Amino Acids Using Pre-column Derivatization. J. Chromatograph-Biomed. Appl. 336: 93-104.

Bligh, E.G \& Dyer W.J. (1959). A Rapid Method Of Total Lipid Extraction And Purification. Canadian Journal Of Biochemistry And Physiology. 37. 917-922

Brandes, C.H. \& Dietrich, R.(1953) In Icekson et al 1998.Lipid Oxidation Levels In Different Parts of The Mackerel, Scomber scombrus. Journal of Aquatic Food Product Technology Vol7 (2) 1998.

Chiou W.D.; Chen, C.Y.; Wang, C.M and Chen C.T. 2006. Food and feeding habits of ribbonfish Trichiurus lepturus in coastal waters of SouthWestern Taiwan. Fisheries Science 72: 373-381

Destura,I \& Haard,N.F. (1999). Development of Intermediate Moisture Fish Patties from Minced Rockfish Meat. Journal of Aquatic Food Product Technology. Vol 8 (2) 77-94.

Granado-Lorencio ,C. (1997) Seasonal changes in condition, nutrition, gonad maturation and energy content in barbell, Barbus sclateri, inhabiting a fluctuating river. Environmental Biology of Fishes. 50 (1):75-84.

Huss, H.H. (1995). Quality and Quality Changes In Fresh Fish. FAO Fisheries Technical Paper No. 348 195pp

Icekson I.; Vladmimir,D.; Aizendorf, S. \& Gelman, A. (1998) Lipid Oxidation Levels In Different Parts of the Mackerel, Scomber scombrus. Journal of
Aquatic. Food Product Technology Vol. 7. (2). 17-29.

KMFRI Ungwana Bay Report (2002) Current Status of Fisheries in the Ungwana bay-Malindi area. A Report by Kenya Marine and Fisheries Research Institute, P.O.Box 81651, Mombasa. 199p

Mathews, K.; Ahmedna, M. \& Goktepa, I. (2003). Value-added Snacks from Defatted Peanut Flour and Fish Mince: Optimizing formulation and Consumer Acceptability. International Food Technology Meeting. Chicago. 2003. 14F-38

Matz, S.A. (1970). Snack Food Technology. West Port: AVI Pub.Co., 1970. 129pp

Muraleedharan, V; Antony, K.P; Perigreen, P.A \& Gopakumar, K (1996). Utilization of unconventional fish resources for surimi preparation. Proceedings of the second workshop on scientific results of FORV SAGAR Sampada, Dept. of ocean development, New Delhi, (India) 539-543.

Muraleedharan, V \& Gopakumar, K. (1997). Suitability of trawl by-catch for surimi preparation . Asia Pacific Fishery Commission. Summary report and papers presented at the tenth session of the working party on Fish technology and marketing. Colombia, Sri-Lanka. 4-7 ${ }^{\text {th }}$ June, 1996. No. 563. 315-319 (FAO Fish. Rep.)

Ogunja,J.C. (1996). Utilisation of Products Of The Nile Perch Processing Industry. FAO Expert Consultation on Fish Technology in Africa, Kisumu, Kenya. Aug. 27-30. FAO Fisheries Report No. 574 . 165-175

Portsev, P.I (1978). The feeding of cutlassfish, Trichiurus lepturus . Journal of Ichthyology.18 (5). 775-781

Schmarr, H.G.; Gross, H.B \& Shabamoto,T. 1996. Analysis of Polar Cholesterol Oxidation Products. Evaluation of a New Method Involving Transesterification, Solid Phase Extraction and Gas Chromatography. Journal of Agricultural Food Chemistry 44: 522-517

Shewan,J.M.; Macintosh, G.R.;Tucker,C.G.;Ehrenberg, A.S.C (1953). The development of a numerical Scoring System for the Sensory Assessment of The Spoilage of Wet White Fish Stored in Ice. J.Sci. Food Agric. 283-296.

Siaw, C.L.; Idrus, A.Z. \& Yu, S.Y. (1985). Intermediate technology for fish cracker ("keropok") production. Journal of Food Technology. Vol. 20. p. 17-21

Taylor, W.R. 1986. Ariidae..Checklist of the fresh water fishes of Africa (CLOFFA ISBN) Brussels, MRAC, Tervuren and ORSTOM, Paris.In J. Daget, J-P. Grosse \& D.F.E Thys Van den Audenaerde (eds). p 153-159

Warm,K.; Niels,B \& Nielsen,J.(1998). Development of Quality Index Methods for Evaluation of 
Frozen Cod (Gardus morhua) And Cod Fillets. Journal of Aquatic Food Product Technoogy. Vol 7(1) 45-58.

Yamada, U. 1991. The reproductive characteristics of the ribbonfish, T. lepturus Linne in the East Coast of China. Bulletin of the Seikai National Fisheries Research Institute. Nagasaki. 41. 63-81.

Yu, S.Y. (1991). Acceptability of Fish Crackers (Keropok) Made from Different Types of Flour. ASEAN Food Journal. Vol. 6. No.3. 114-116 
